\title{
English and Scottish Scholars at the Library of Gian Vincenzo Pinelli (1565-1601)
}

\author{
JOHN-MARK PHILO \\ University of East Anglia
}

Throughout the second half of the sixteenth century, the scholar and collector Gian Vincenzo Pinelli (1535-1601) welcomed poets, mathematicians, antiquarians, and astronomers from every corner of Europe to his vast private library in Padua. These scholars left their mark on Pinelli's collection, annotating his manuscripts, trading texts, and even making contributions of their very own to his library. This article considers the English and Scottish scholars who visited Pinelli's collection and the works they gifted to Pinelli. These manuscripts, now preserved at the Biblioteca Ambrosiana, Milan, include an impressive breadth of material, ranging from treatises on England's schism with Rome to verse commemorating the deaths of fellow scholar-poets. Pinelli, it emerges, was not only hosting scholars from England and Scotland, but also gathering reports, discourses, and what was in many cases highly sensitive intelligence on both nations. These manuscripts thus bear witness to the importance of the Italian private library to the transmission of both ideas and physical texts across the Continent, shining new light on a literary culture that was able to cross and transcend national boundaries.

Durant la seconde moitié du seizième siècle, l'érudit et collectionneur Gian Vincenzo Pinelli (15351601) a mis sa vaste bibliothèque privée padouane à la disposition de poètes, de mathématiciens, d'antiquaires et d'astronomes originaires de toute l'Europe. Ces érudits ont laissé leur marque sur la collection de Pinelli en annotant ses manuscrits, en échangeant des textes et en ajoutant même leurs propres contributions à cette bibliothèque. Cet article considère les érudits anglais et écossais qui ont visité la collection de Pinelli, ainsi que les ouvrages qu'ils lui ont offerts. Ces manuscrits, qui sont présentement conservés à la Biblioteca Ambrosiana à Milan, forment un ensemble impressionnant de matériaux, allant des traités portant sur le schisme de l'Angleterre vis-à-vis de Rome, à des vers commémorant la mort d'autres intellectuels et poètes. Pinelli, semble-t-il, ne se contentait pas d'héberger des érudits d'Angleterre et d'Écosse, mais réunissait également des rapports, des discours et ce qui s'avère être dans plusieurs cas des renseignements hautement confidentiels sur ces deux nations. Ces manuscrits témoignent ainsi de l'importance de cette bibliothèque privée italienne dans la transmission à la fois des idées et des textes matériaux à travers le continent européen, en jetant un nouvel éclairage sur une culture littéraire qui a su traverser et transcender les frontières nationales.

\section{Introduction}

This article examines the place of English and Scottish scholars at the
vast private library of the humanist and collector, Gian Vincenzo Pinelli 
(1535-1601). Throughout the second half of the sixteenth century, Pinelli hosted English and Scottish poets, astronomers, mathematicians, and antiquarians at his home in Padua, many of whom left their mark on his collection, whether annotating manuscripts or making contributions of their very own to his library. This article focuses on four authors and the works they contributed to Pinelli's collection: the astronomer Edmund Bruce, the diplomat Sir Richard Shelley (ca. 1513-87), the antiquarian Richard White (1539-1611), and the poet Thomas Seget (ca. 1570-1627). These manuscripts, now preserved at the Biblioteca Ambrosiana, Milan, attest not only to the English and Scottish presence at Pinelli's library but also to his enduring interest in the two nations. Pinelli was collecting an extraordinary quantity of material on the cultural and political dimensions of Scotland and England, from descriptions of English mores to contemporary accounts of rebellions under Elizabeth I (1533-1603). This article locates the works by Bruce, Shelley, White, and Seget in the wider context of Pinelli's study of England and Scotland, exploring the means by which Pinelli gathered what was often highly sensitive intelligence concerning the two nations. These manuscripts also speak of the attempts of Catholic Englishmen in Italy to reconcile their dual and conflicting identities as faithful citizens of a Protestant state and devoted servants of the Church of Rome. Shelley, eager to reassert the importance of England in the early development of Christianity, penned a tract on Britannia as the birthplace of Constantine the Great, while White, a Roman Catholic, wrote his Historiarum Libri (1597) for the "sweet love of the homeland." As this article explores, there is in fact implicit in all these works the complex negotiation of identity in a collaborative and, by its nature, culturally diverse environment.

Marcella Grendler has examined the Greek works in Pinelli's library, identifying Pinelli as not only a collector but also an enthusiastic supporter of "scholars in every imaginable field." 2 More recently, Angela Nuovo has explored the political, social, and bibliographic dimensions of the collection, arguing, not without reason, that Pinelli's library was "in some ways [...] the

This research was undertaken through an Early Career Fellowship awarded by the Leverhulme Trust. I would like to express my thanks to the librarians of the Biblioteca Ambrosiana for their advice and patience.

1. Richard White, Historiarum Libri (Arras: Guillaume de la Rivière, 1597), 5.

2. Marcella Grendler, "A Greek Collection in Padua: The Library of Gian Vincenzo Pinelli (1535-1601)," Renaissance Quarterly 33.3 (1980): 386-416, 386. 
most important library in sixteenth-century Italy." ${ }^{3}$ While previous studies have illuminated specific relationships fostered between Pinelli and scholars across the Continent, this article, uncovering a series of hitherto unstudied manuscripts at the Ambrosiana, focuses on the works of English and Scottish authorship in Pinelli's celebrated collection. ${ }^{4}$ As Nuovo observes of Italy's private libraries more generally, they "acted not only as places where written documents were arranged and stored, but also as sites of cultural exchange [and] places of reading 'in dialogue."'5 By examining the literary coterie surrounding Pinelli from which these works emerged, and by exploring the complex relationships fostered between Pinelli and his transnational guests, this article adds further evidence of the Italian private library as a space of scholarly collaboration and shared reading. The findings explored here also add to the rich corpus of critical work on cultures of communication in early modern Europe, which has in recent years been bolstered by online projects including the University of Stanford's Mapping the Republic of Letters and Early Modern Letters Online, courtesy of the Cultures of Knowledge Project. ${ }^{6}$ By focusing specifically on Pinelli's collection as a centre of cultural and epistemological exchange, this research shines some new light on how the Italian private library fostered and encouraged such transnational relationships.

\section{Padua, Pinelli, and travel abroad}

Your fellow-countrymen, the English, are wont beyond other nations to visit me often, especially in the summer, whom (as is fitting) I value and

3. Angela Nuovo, "The Creation and Dispersal of the Library of Gian Vincenzo Pinelli," in Books on the Move, ed. Robin Myers, Michael Harris, and Giles Mandelbrote (London: Oak Knoll Press and the British Library, 2007), 39-67, 39. See also Nuovo, "Manuscript Writings on Politics and Current Affairs in the Collection of Gian Vincenzo Pinelli (1535-1601)," Italian Studies 66.2 (2011): 193-205.

4. Natáliá Ruonáková, “The Correspondence of Nicasius Ellebodius Casletanus to Gianvincenzo Pinelli," Bolletino di italianistica 9.1 (2012): 131-44; Gian Vincenzo Pinelli and Claude Dupoy, Une correspondance entre deux humanistes, ed. Anna Maria Raugei (Florence: L.S. Olschki, 2001).

5. Nuovo, "Manuscript Writings", 193-204, 193-94.

6. Early Modern Letters Online, accessed 4 Nov 2018, emlo.bodleian.ox.ac.uk/; Mapping the Republic of Letters, online, accessed 4 Nov 2018, republicofletters.stanford.edu/. For recent studies of such exchanges, see the essays gathered in Ann Blair and Anja-Silvia Goeing, eds., For the Sake of Learning: Essays in Honor of Anthony Grafton (Leiden: Brill, 2016); Pietro Daniel Omodeo, ed., Duncan Liddel (1561-1613): Networks of Polymathy and the Northern European Renaissance (Leiden: Brill, 2016). 
with whom, as each one's nature or desire inclines, I converse freely on whatever subject has been proposed. ${ }^{7}$

Thus wrote the Danish astronomer, Tycho Brahe (1546-1601), to the scholar Thomas Savile (d. 1593), speaking of the steady flow of visitors he received from England at the Uraniborg observatory on the island of Ven. That travel abroad was an attractive prospect to the youth of both Tudor England and Stewart Scotland has been well documented. ${ }^{8}$ As Jonathon Woolfson notes, "foreign travel was becoming an educational institution no less real than the places of learning in England where most travellers had spent some time immediately prior to their departure." Long before the Grand Tour of the late seventeenth and eighteenth centuries, Italy's celebrated universities were attracting English and Scottish students and scholars alike. Thus in 1549, William Thomas (d. 1554) wrote of the international renown that the Italian universities already enjoyed:

I thinke verilie, that in one region of all the worlde againe, are not halfe so many straungers as in Italie: specially of gentilmen, whose resorte thither is principallie vnder pretence of studie. For there are diuerse famouse citees, that be priuileged with great libertees for all scholars that come: as Padoa, Bononia, Pauia, Ferrara, Pisa, and others: in euery one of the whiche, are excellente learned men, waged for the readyng of philosophie, of the ciuile laws, and of all the liberall sciences. ${ }^{10}$

It is no accident that Thomas, who had himself travelled extensively in Italy, lists "Padoa" first and foremost among the Italian university towns, which was to become the single most popular destination for English students abroad during

7. British Library (hereafter “BL”) Harley MS 6995, 21 $1^{\mathrm{r}}$ : “Solent præter alias nationes diuersas tui quoque Conterranei Angli me quotannis, æstatis præsertim tempore crebro invisere, quos et, uti par est, in pretio habeo, et prout cuiusque fert ingenium atque desiderium, libenter cum illis de re qualibet proposita confero." All translations are my own.

8. Jonathon Woolfson, Padua and the Tudors (Cambridge: James Clarke and Co., 1998); Sara Warneke, Images of the Educational Traveller in Early Modern England (Leiden: Brill, 1995).

9. Woolfson, 124.

10. William Thomas, Historie of Italy (London: Thomas Berthelet, 1549), $2^{\mathrm{v}}-3^{\mathrm{r}}$. 
the sixteenth century. ${ }^{11}$ Of those English scholars who have left traces of their study at Pinelli's library, the majority had also matriculated at Padua; Edmund Bruce, Richard White, Thomas and Henry Savile (1549-1622), and Henry Cuffe (1562/3-1601) were all alumni of the natio Anglica. ${ }^{12}$ The university was equally attractive to students north of the border, including the poet Thomas Seget, Robert Ker, Patrick Sandys, Thomas Murray, and John Ruthven, third earl of Gowrie (1577/8-1600), who in fact spent a year as its rector. So too the poet, translator, and courtier William Fowler (1560/1-1612) attended the natio Scota. Thanks to his scholarly and poetic pursuits at Padua and Venice, Fowler served as "the biggest single influence in spreading a knowledge of Italian literature throughout Jacobean Scotland." ${ }^{13}$ Padua held then a firm reputation throughout the sixteenth century in Scotland and England alike as the "nursery of arts." 14

It was not only the university, however, which attracted scholars from these two nations. Pinelli's library functioned as a meeting place for the greatest minds of the age, drawing scholars and artists of every discipline. As the Vita del Padre Paolo (1646) puts it, "the house of Vincenzo Pinelli [...] was the home of the Muses and the academy of all virtues in those times." ${ }^{15}$ Pinelli went beyond merely allowing scholars to consult his collections and in fact welcomed them into his home for extended periods of study. As Paolo Gualdo explains in his biography of Pinelli, "he received into his home with a happy heart a number of learned men, with whom he could discuss literary matters at leisure and without interruption." ${ }^{16}$ Here "contubernium," which in its root sense was

11. For the Italian elements of Thomas's literary output, see Cathy Shrank, Writing the Nation in Reformation England, 1530-1580 (Oxford: Oxford University Press, 2004), 104-42. Woolfson, 5.

12. For Henry and Thomas Savile at Pinelli's library, see Robert Todd, "Henry and Thomas Savile in Italy," Bibliothèque d'Humanisme et Renaissance 58.2 (1996): 439-44; John-Mark Philo, "Henry Savile's Tacitus in Italy," Renaissance Studies 32.5 (2018): 687-707.

13. R. D. S. Jack, “William Fowler and Italian Literature,” The Modern Language Review 65.3 (1970): 481. 14. William Shakespeare, The Taming of the Shrew, 1.1.2, in The Complete Works, ed. Jonathan Bate and Eric Rasmussen (Basingstoke: MacMillan, 2007) 536.

15. Fulgenzio Micanzio, Vita del Padre Paolo (Leiden: s.n., 1646), 74: "la casa di Vicenzo Pinelli [...] era il recetto delle Muse, e l'Academia di tutte le virtù in quei tempi."

16. Paolo Gualdo, Vita Ioannis Vincenti Pinelli (Augsburg: Christophorus Mangus, 1607), 52r: "recepit lubenti animo in contubernium doctos aliquot viros, quibuscum disserere de re litteraria continenter \& per otium posset." 
used of soldiers sharing the same tent, speaks of the intimacy with which Pinelli hosted and entertained his scholarly visitors. ${ }^{17}$ In a letter to the same Gualdo, the archaeologist Lorenzo Pignoria (1571-1631) employed a similar idiom, speaking of Erycius Puteanus as "that noble housemate [contubernalis] of Pinelli," where "contubernalis" suggests literally "one who shares the same tent." ${ }^{18}$ Intriguingly, the word was also used of a junior officer attached to a general's retinue for training, suggesting something of the pedagogical qualities at work in this exchange: Pinelli was admitting younger scholars into his home to nurture and extend their scholarly pursuits. ${ }^{19}$

The visitors to Pinelli's library not only consulted but frequently contributed to its collections. The works by Scottish and English authors emerged from an atmosphere of scholarly reciprocity and exchange, to which an anonymous letter to Pinelli (signed only by three pentacles) bears witness:

I am returning to your lordship with many, many thanks your two copies, one of Signor Aldobrandino, the other of Father Latino Latinus. [...] Having entered a bookshop yesterday to wait for my Signor who had sent me nearby, I found by chance that he was folding and binding a French Livy, in the translation by Vigenère, from which I wanted to copy two places (which I did with haste) and am sending you copied out again for you to consider their meaning at home. ${ }^{20}$

The speaker, returning the books he has borrowed from Pinelli's library, has come across a copy of Vigenère's French translation of Livy's A $b$ Urbe Condita (published in 1583 as Les Decades) and has copied out those moments which

17. OLD, s.v. "contubernium," 1. Oxford Latin Dictionary, Second Edition, ed. P. G. W. Glare (Oxford: Oxford University Press, 2012).

18. Lorenzo Pignoria, Laurentii Pignorii Symbolarum Epistolicarum (Padua: Joannis Baptista de Martinis, 1628) 70. Liber OLD, s.v. "contubernalis," 1.

19. OLD, s.v. "contubernalis," 1 b.

20. "Io rimando a Vostra Signoria molto Illustre con molte et molte gratie, le due copie sue l'una del Sr. Aldobrandino, l'altra del Pr. Latino Latinio. [...] Et essendo hieri intrato nella bottega d'un libraro per aspettar il mio segnor c'hauea mandato la appresso, trouai a sorte che piegava per ligar un T. Liuio francese della traduttion di Vigenaire, dalla quale volsi copiar, come feci in fretta Ii due luoghi, che mando insieme ricopiati, per considerar poi in casa il suo senso sopra d'essi." Biblioteca Ambrosiana (hereafter "BA") MS P 167 sup.: unità codilogica 13, 31. 
he thinks will be of special interest to Pinelli. ${ }^{21}$ This letter speaks not only of Pinelli's openness with his collection but also of the fact that this sharing was a two-way process-the users of his library were expected to offer Pinelli their own scholarly insights, analysis, and even original works in return. His English and Scottish visitors were no exception, whether providing Pinelli with their observations on Henry VIII's schism with Rome or expounding upon the finer points of English archery. It was precisely in this spirit of scholarly reciprocity that Thomas Savile wrote when he sent Pinelli his "Conjecture on Strabo": "I am returning the Strabo to your lordship together with three other books, for which I give you the utmost thanks [...] I am also sending you that little work which I made on the places where he speaks of Italy." 22 Once again, the reader returns the books he was able to borrow from Pinelli, contributing also his personal addition to the collection. The section that follows examines the contributions made by Edmund Bruce and Richard Shelley to Pinelli's library, locating these within the rich store of material which Pinelli was assembling on England and Scotland more generally.

\section{Pinelli’s Britannia: politics, ethnography, and antiquarianism}

Pinelli gathered a remarkable quantity of material concerning the political and cultural composition of England and Scotland and the often fraught relations between the two countries. These documents offer a fascinating insight into Italian perceptions of England and Scotland in the sixteenth century, and suggest the kinds of information that were of special value and interest to an Italian readership. Ambrosiana Manuscript C64 inf., for instance, contains an impressive array of material relating to the English and Scots alike. The manuscript is prefaced with an anonymous work in Italian entitled "On the Nature of the English and their Customs" ("Della Natura degli Inglesi e loro Costumi"). The treatise appears to have been composed during the reign of Henry VIII (1491-1547), referring to "the King" and his break with the Catholic Church. ${ }^{23}$ Here the English nobility are presented as luxuriant spendthrifts, who

21. Livy, Les Decades, trans. Blaise de Vigenère (Paris: chez Nicolas Chesneau, 1583).

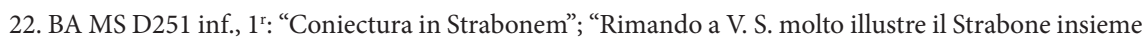
co' tre altri libri, de' quali tutti e quattro io le rendo somme gratie [...] le mando ancora quel poco ch'io ho fatto intorno a i luoghi doue parla dell'Italia."

23. BA MS C64 inf., $5^{\mathrm{v}}$. 
dine for hours at a time and holiday as often as possible to flee the company of the commons:

The English are in general wasteful with their earnings, eat often and at length, and with ostentatious display stay for two, three, four hours at the table, not so much continually eating, as courteously entertaining the ladies. [...] The nobles holiday with alacrity, fleeing the indolence and incivility of the commons in each city. ${ }^{24}$

There is a curious proximity between the alleged extravagance of the English aristocracy, as viewed through Italian eyes, and those stereotypes concerning the Italians cultivated by Tudor authors. Thus Thomas Nashe's (bap. 1567, d. ca. 1601) Unfortunate Traveller (1594) speaks of Italy as "the paradise of the earth, and the Epicure's heaven," where a young man may study "the art of epicurising," while Roger Ascham (1514/15-68) offered a more general warning for the English student abroad who will inevitably discover "plentie of new mischieues neuer knowne in England before," including "filthy lyuing" and "the inchantementes of Circes." 25 It appears then that charges of extravagance and luxury cut both ways across the Continental divide.

The author of the treatise touches also on the international composition of the English court, noting that "the king has many Italians and Spaniards of every profession in his service, who enjoy the good company of the courtiers, that devote themselves to the French and to the Italian language." ${ }^{26} \mathrm{He}$ goes on to explain the value that the English nobility place on education and even links the study of "buone lettere" ("good letters" or "fine literature") among the English youth with the development of English Protestantism: "those who have to stand out make their sons and daughters study Latin, Greek, and Hebrew, from which befell this heretical tempest in the kingdom, by persuading themselves that it is

24. BA MS C64 inf., $1^{\mathrm{r}}-3^{\mathrm{r}}$ : “Gl'Inghilesi in generale sono prodighi delle intrate loro, pasteggianno spesso, et lungamente, et con pompa stanno dua, tre, quattro a tavola, non tanto sempre mangiando, quanto trattenendo gentilmente le donne [...] I nobili villegiano uolentieri fuggendo l'ignauia, et la discortesia della Plebe d'ogni città."

25. Thomas Nashe, The Unfortunate Traveller (London: T. Scarlet for C. Burby, 1594), L4; Roger Ascham, The Scholemaster (London: Johne Daye, 1570), 26v.

26. BA MS C64 inf., 5: "il Re medesimo ha molti Italiani e spagnoli al suo seruitio d'ogni professione i qauli hano buona compagnia da i cortegiani che attendano alla lingua Franceze, et alla Italiana.” 
useful for each and everyone to understand sacred scripture from its origin." ${ }^{27}$ The author thus presents the break with Rome as a product of humanist education and its emphasis on returning ad fontes, whether to the classical or scriptural original, a principle which was at work from the earliest years of the Reformation in regard to the Holy Writ. ${ }^{28}$ For at least one Italian observer, then, there was a direct correlation between English pedagogy and the development of reformist thought.

Pinelli himself was writing his own notes on the English and Scots. At one moment, he contrasts the tonal differences of the English and French languages, and at another, compares English Puritans with those of Geneva. ${ }^{29}$ In another manuscript collection, he writes candidly that "in the Scotsman one sees great intellect and great readiness, but a complete lack of judgement." ${ }^{30}$ He appears also to have invited his English acquaintances to comment on and correct Italian accounts of England. The same manuscript that includes Shelley's argument concerning the British heritage of Constantine the Great (ca. 274-337) also features a short "Report on England" ("Relazione d'Inghilterra”), which examines the political structures of England in detail. ${ }^{31}$ This piece also includes, however, a list of corrections in a different hand that has been added at a later date:

[page] 6, line 23 "porchshai." Read "Shires," which means "counties."

[page] 7, line 18 "Conte di Westmerland.") Here it appears that the person who has written this account has never been to England but has merely stolen everything he says from others: for it is more than twenty years since there has been a Count of Westmorland in England, nor indeed have the English used the bow for thirty years or more; and on account of this it appears that he is speaking according to an old report [...].

27. BA MS C64 inf., 5v: "quelli che hanno da splendere fanno studiare i figliouoli, et le figliouole, latino greco, et Hebreo, da poi che cadde quella tempesta di heresia nel Regno, per suadendosi esser utile ai ciascuno, intendere la sacra scrittura dal suo origine."

28. Euan Cameron, The European Reformation (Oxford: Oxford University Press, 1991), 163-68.

29. BA MS N278 sup., 59r; BA MS I186 inf. 5, $189^{\text {r. }}$

30. BA MS N278 sup., 24v: "nello Scozzese si vede gran mente et gran prontezza, ma pochissimo guidizio." 31. For Pinelli's collecting of Venetian relazioni, see Filippo de Vivo, "How to Read Venetian Relazioni," Renaissance and Reformation 34.1/2 (2011): 25-59, 45. 
[page] 22. What he says concerning the High Chancellor is entirely contradictory and for this reason (and many others besides) it seems to me that the person who has made this account doesn't know what he is saying. ${ }^{32}$

Here the grammatical slips ("ha stato" for "è stato"; "usati” for "usato") suggest a speaker whose first language is not Italian, while the familiarity with English political frameworks and indeed with English vocabulary more generally point to a native English speaker, or at the least someone who had gained (unlike the author he rebukes) direct experience of England. The reference to Charles Neville (1542/3-1601), Earl of Westmorland, and his forfeiting of that title more than twenty years before, dates these comments to around the $1580 \mathrm{~s}$, when Sir Henry Savile was visiting the library. Neville had played a key role in the northern rebellion of 1569, which sought both to liberate Mary Stewart from her imprisonment in Staffordshire and to reinstate the Catholic faith, two themes that run throughout the documents that Pinelli collected on England and Scotland. Pinelli had in fact acquired a copy of the proclamation issued in response to Neville's uprising, originally published in 1569 by the royal printers, John Cawood (1513/14-72) and Richard Jugge (ca. 1514-77). ${ }^{33}$

It was with an eye to explaining "the Nature of the English and their customs" that Edmund Bruce composed his treatise "On the English Bow" for Pinelli, dated “14. Dec. [15]93.” Bruce was an English astronomer who counted among his acquaintance at Padua the antiquarian Lorenzo Pignoria (15711631), as well as his fellow scientists Giovanni Antonio Magini (1555-1617) and Galileo Galilei (1564-1642). ${ }^{34}$ A gifted scientist and scholar in his own right, Bruce was engaged in an extended correspondence with the celebrated

32. BA MS $\$ 93$ sup., $190^{\mathrm{r}}$ :

6, 1. 23 "porchshai. lege Shires che vuol dire Contadi"

7, 1.18 "Conte di Westmerland.) qui appare che quello chi a fatto questa relazione non ha mai stato in Inglaterra ma solo derubato tuto quello dice [...] di altri: perche è piu di 20 anni che non fu nisuno Conte di Vestmerlandia in Inglaterra, ni ancora di 30 e piu anni gli Inglesi non hanno usati l'arco; et per questo appare che parla secondo relazione vecchia $[\ldots]$ ”

22, 1. 26. "quel che parla del grand Tesoriere è tutto al contrario e per questo con molte altre cose mi pare che non sa che dise quello che ha fatto questa relazione."

33. BA MS D489 inf., unità codicologica 131. Cf. Elizabeth I, "By the Queene. The Queenes Maiestie was sundry wise [...]” (London: Richard Jugge and John Cawood, 1569).

34. Woolfson, 215. 
German astronomer, Johannes Kepler (1571-1630). ${ }^{35}$ During the 1590s, Bruce began sending intelligence from Padua to Anthony Bacon (1558-1601), who had himself been employed on the Continent as an intelligencer by William Cecil (1520/21-98) and Sir Francis Walsingham (ca. 1532-90) over a decade before. ${ }^{36}$ Bruce enjoyed a close friendship with Pinelli. Indeed, he was the only Englishman to receive a special mention in Pinelli's biography, where Gualdo refers to him as "the noble Englishman." ${ }^{37} \mathrm{He}$ could also rely on Pinelli's farreaching influence to access the Tabula Peutingeriana, the thirteenth-century map depicting Roman military routes of the Western Empire. ${ }^{38}$

Preserved in the same manuscript as the Italian treatise on English customs, Bruce's work on English archery has been copied in an elegant hand and is exquisitely illustrated throughout, from depictions of the bow's composite parts to the trajectory of an arrow in flight. In writing his treatise, Bruce followed in the footsteps of Roger Ascham, who had composed Toxophilus: The Schole of Shootinge (1545) to celebrate Henry's capture of Boulogne, where he praised archery as "a pastime, honest for the minde [and] holsome for the body." ${ }^{39}$ Whereas Ascham wrote "this English matter in the Englishe tongue, for Englishemen," Latin was the scholarly lingua franca at Pinelli's library, and it was in Latin that Bruce composed his gift. ${ }^{40}$ Sensitive to Pinelli's philological interests, however, he has peppered the treatise with English vocabulary and phrases, and thus "Flecthers," "By[r]che tree," "Buzboult," "To shot at Rouers," "the Pricke in the Wyght," all appear with accompanying explanations in Latin. ${ }^{41}$ Intriguingly, the scribe responsible for copying Bruce's original manuscript appears to have been unfamiliar with English and has thus

35. Robert Westman, The Copernican Question: Prognostication, Skepticism, and Celestial Order (Berkeley: University of California Press, 2011), 365.

36. Alan Stewart, "Bacon, Anthony (1558-1601)," Oxford Dictionary of National Biography (Oxford: Oxford University Press, 2004) (henceforth ODNB); online (Jan 2008 edn.), accessed 15 Oct 2017, oxforddnb.com/view/article/988.

37. Gualdo, 43.

38. Bruce thanks Pinelli for his assistance in a letter now preserved in two copies: BA MS R104 sup., $237^{\mathrm{r}}-238^{\mathrm{v}}$.

39. Roger Ascham, Toxophilus: The Schole of Shootinge (London: Edmund Whytchurch, 1545), Aiiir.

40. Ascham, Toxophilus, Aiiir.

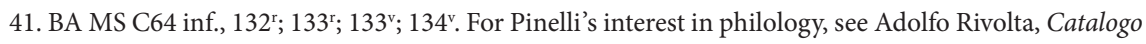
dei Codici Pinelliani Dell'Ambrosiana (Milano: Typografia Pontificia, 1933), LXVI. 
mistaken the $\mathrm{f}$ in "shaft" for a long s, thus producing "Shast heads," "a Rouinge Shast," "prickshast," and "Butt shastes." ${ }^{22}$ This speaks of the status of English among the European languages more generally in the early modern period, lagging some way behind French, Italian, and German. When the Englishman of John Florio's (1553-1625) First Fruits (1578) asks his Italian interlocutor how he rates the English language, he replies bluntly that "it is a language that wyl do you good in England, but passe Dover, it is worth nothing." ${ }^{43}$ It is all the more remarkable, then, that Pinelli appears to have taken an active interest in the language. ${ }^{44}$

There is a playful quality to Bruce's prose. He is not above patriotic one-upmanship_ “the bow strings are the same as the Italians', except that they are tougher and made from better rope" - and at one moment he coins a neologism ("sagittastitio," literally "arrow-placing," but punning on the sagacitas, or "keenness," of the skilful marksman). Explaining that the English have since antiquity instructed their youth in archery to prepare them for war, he juxtaposes the visually similar "belle" ("finely"), "in bello" ("in war"), and "imbelles" ("unwarlike"). ${ }^{45}$ In his conclusion, he plays on literal and figurative coolness, writing as he was in the middle of December: "the bow is also protected from the cold in a sheath made from cloth; but in case, while I speak of the cold in this cold, my wit cools at the same time as the material itself, all that remains (lest I abuse your patience any longer, most distinguished of men) is for me to bring this my cold discourse to a close." ${ }^{46}$ Though there are clearly instructive elements at work here, Bruce's treatise exhibits a kind of intellectual play between the two scholars, and its giving and receiving thus functions as not only an expression of their friendship but also a recognition of their mutual learning and ease with the Latin language.

\section{BA MS C64 inf. $133^{\mathrm{v}} ; 135^{\mathrm{r}} ; 134^{\mathrm{r}}$.}

43. John Florio, Florio His First Fruites (London: Thomas Dawson for Thomas Woodcocke, 1578) $50^{\mathrm{r}}$.

44. Pinelli's notes on the English language are preserved in the "Miscellanea di annotazioni critiche," BA MS I186 inf., unità codicologica 5.

45. BA MS C64 inf. $134^{\mathrm{r}}$.

46. BA MS C64 inf. 137v: "Chordae similes Italianis nisi quod duriores et ex meliori canabe factae sunt"; 138v: "praeseruatur etiam Arcus a frigore in theca ex panno facta; sed ne dum de frigore in hoc frigore loquor ubi inegenium meum simul cum ipsa materia frigescat; et quod reliquum est ne amplius abutar tua patientia (Vir Illustrissime) hoc meo frigido sermone hic finem faciam." 
Besides more general works on English customs and political structures, Pinelli was also collecting material on Henry's schism with Rome and its consequences at home and further afield. He owned, for example, at least part of Shelley's commentary on Henry's divorce from Catherine of Aragon (14851536), as well as an Italian account of "the death of Thomaso Moro." ${ }^{47}$ Pinelli was also collecting poetic responses to Henry's reign, including an early poem addressed to the king by the Italian humanist Lazzaro Bonamico (1477-1552), and an anonymous epitaph written in the voice of Henry's fifth wife, Katherine Howard (ca. 1518-24 to 1542):

While my young mind indulged in the finer things,

Blind love prepared his weapons for me, unsuspecting.

And I married together forbidden passion and a royal wedding,

And from here came the tears, from here the punishment

to be paid for a violated bed

[...]

Who is it that, throat freshly-cut by iron, made wet by blood,

You have buried with many tears in this tomb?

I am that wife of the British king, Katherine,

Fifth to be placed in the bed of Henry VIII.

What was the shameful cause that betrayed this tender

Neck to the axe? Alas, the rumour of injured chastity. ${ }^{48}$

There are distinctly Virgilian undertones at work here, with a particular emphasis on the Dido and Aeneas narrative of Aeneid IV. The appearance of "rumour" ("fama") in the last line recalls Virgil's digression on the same in the wake of

47. Richard Shelley, "Commentarii Ricardi Scelleii [...] De Prima Caussa, et Progressu vulgo nominate

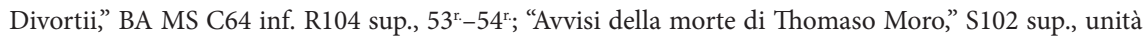
codicologica 4 .

48. BA MS S80 Sup., 281': "Mens dum luxuriat rebus iuuenalis opimis / Caecus in incautam tela parauit amor. / \& iunxi vetitos taedis regalibus ignes, / Hinc lachrimae, hinc laesi poena luenda thori. [...] Quae ferro iugulata recens madefacta cruore / Et lachrimis multis conderis hoc tumulo? / Illa ego sum Regis coniunx Catharina britani, / Henrici octaui quinta locata thoro. / Ceruices teneras quae causa indigna securi / Prodidit? Heu fama laesae pudicitiae." Cf. Lazzaro Bonamico, "Carmen ad Henricum VIII Angliæ Regem," BA MS D450 inf.: unità codicologica 33. 
Dido and Aeneas's visit to the cave: "Rumour, than which there is no evil faster." 49 Virgil's Fama spreads word that Aeneas and Dido have lost themselves in lust, much as Katherine describes herself at the beginning of the poem ("incautam" suggesting "unguarded" or "unsuspecting"), where "luxuriat" picks up Virgil's "luxu": "now they keep each other warm the winter long in their debauchery ["luxu"], heedless of their kingdoms, captured by shameful desire." ${ }^{50}$ The sense of compromised chastity cited in the last line ("injured chastity") is also to be found throughout the Dido episode, where she speaks of her "chastity destroyed." 51 The phrase "placed in the bed" ("locata thoro") carries undertones of both marriage and death: "locare puellam" (literally "to place a girl") was used to suggest "to give in marriage," while "torus" was used not only of the marital bed but also of the palliasse placed under a corpse for cremation. ${ }^{52}$ Here torus recalls more specifically the bed on which Dido commits suicide at the end of book 4, while the wedding torches ("taedis") draw on Virgil's repeated use of the same throughout the Dido episode. ${ }^{53}$ With this nod to Dido and her suicide, the bed Katherine shared with Henry is thus presented as being intimately linked with her death. The most explicit resonance with Dido, however, draws not on the Aeneid but rather on an epigram attributed during the Renaissance to Ausonius, which takes Virgil's account to task for its alleged inaccuracies. As Sir Walter Raleigh (1554-1618) translates it in The Historie of the World (1617),

I am that DIDO which thou here do'st see,

Cunningly framed in beauteous Imag'rie.

Like this I was, but had not such a soule,

As MARO fained, incestuous and foul. ${ }^{54}$

49. Virgil, Aeneid, P. Vergili Maronis Opera, ed. R. A. B. Mynors (Oxford: Clarendon Press, 1969) 4.174: "Fama, malum qua non aliud velocius ullum.".

50. Virgil, Aeneid, 4.193-4: "nunc hiemem inter se luxu, quam longo, fovere / regnorum immemores turpique cupidine captos."

51. Virgil, Aeneid, 4.322: “extinctus pudor." See 4.27, 55.

52. OLD s.v. “loco," 6; s.v. “torus," 5, 4b.

53. Virgil uses "torus" four times in the description of Dido's death: Aeneid, IV.508; 650; 659; 691. For “taedae," see Aeneid, 4.18, 339, 505.

54. Walter Raleigh, The History of the World (London: William Stansby for Walter Burre, 1617) 547; "Illa ego sum Dido uultu, quam conspicis hospes, / assimulata modis, pulchraque mirificis. / Talis eram, sed 
With "Illa ego sum [...] coniunx" ("I am that wife"), the Katherine epitaph harnesses the epigram's "Illa ego sum Dido" ("I am that DIDO"), deliberately echoing in its closing lines the opening words of this revisionist account of the Dido narrative. It was to escape the aggressive advances of Iarbas, the Dido of the epigram explains, that she took her life, "not mou'd by furious loue or iealousie," and she concludes by urging her listeners to show discernment with regard to their sources: "Readers, beleeue Historians; not those / Which to the world IOVES thefts and vices expose." ${ }^{55}$ In this light, it is telling that the Katherine poem speaks in its conclusion of "the rumour of injured chastity," as opposed to the fact. By drawing on the Dido epigram, the epitaph offers the reader similar pause for thought when considering Katherine's alleged misconduct. There was then for a Continental audience clearly a compelling if horrific spectacle in Katherine's execution ("a spectacle for the crowd," as the epitaph puts it), but perhaps also some reservation concerning her condemnation by Henry. Katherine is as much a victim of rumour as Dido was. ${ }^{56}$

Henry's break with Rome and the European ramifications of English Protestantism can be felt acutely in the works by Shelley preserved in the Pinelli papers. Shelley was, towards the beginning of his career at least, a successful diplomat and prior of the hospital of St. John in England. Though the Knights Hospitaller were supressed under Henry, following the accession of Mary I (1516-58) Shelley was able to resume his membership of the order, and in 1558 he began the journey to Malta. When Elizabeth succeeded to the throne, however, Shelley was effectively left stranded on the Continent. He spent the last years of his life in Venice, where, still loyal to the English crown, he was "hated by the émigré Catholic militants and strongly opposed the Jesuits." 57 It was during this time that Pinelli added Shelley's works to his ever-growing collection, including a treatise on the British origins of Constantine the Great,

non, Maro quam mihi finxit: / Vita nec incestis læta cupidinibus” (Ausonius, Opuscula Varia [Lyon: Sébastien Gryphe, 1537], 44).

55. Raleigh, 547; "Non furor, aut læso crudus amore dolor"; "Vos magis historicis lectores credite de me, / Quam qui furta deum concubitusque canunt” (Ausonius, 44).

56. BA MS S80 Sup., 281: “spectacula vulgo.”

57. Michael Mullett, "Shelley, Sir Richard (c.1513-1587)," ODNB; online, accessed 6 Oct 2017, oxforddnb. com/view/article/25313. 
as well as a "Prayer to God" in which he asks for "the patience of Job" to endure his "exile, however long and wretched." 58

Shelley's twin identity as devoted subject and devoted Catholic (a position that evidently came at great personal cost) underpins the works preserved at the Ambrosiana. On 4 January 1586, Pinelli received Shelley's Enquiry, Wherein It Is Deduced that Constantine the Great was British by Birth. Highly self-conscious of the status of England on the Continent, Shelley goes to great lengths to associate Britannia with this celebrated Roman patron of Christianity:

Constantine, surnamed "The Great," chosen by God, who [...] liberated Italy from tyranny, enriched the church (hitherto poor) with a gift of such great wealth, and through divine influence endowed the supreme pontiff, while he was seeking first the kingdom of God, with the promised badges of honour, was born in England to British Helen, then venerable, now divine, as the testimonies of the following authors reveal. ${ }^{59}$

With "first seeking the kingdom of God," Shelley presents the pope as directly following Christ's exhortation during the Sermon on the Mount-"seke ye first the kyngdome of God"-while the "gift of such great wealth" nods to Constantine's donation of the Lateran Palace to the bishop of Rome. ${ }^{60}$ Shelley subsequently appeals to the authority of Pope Julius III (1487-1555), who in 1553 had appointed Reginald Pole (1500-58) as papal legate to England, citing a debate between the pope and his cardinals on the origins of Constantine. "Britannia," Julius explains, "was itself the first of the provinces to accept the Christian faith, which it has protected thereafter all the way down to our time (despite certain kings deviating at moments and occasionally raging

58. BA MS R109 sup., 247v: "JOBEA [...] patientia”; “exilium, quantumvis licet longum, atque ærumnosum."

59. “Animadversio qua colligitur Constantinum Magnum fuisse Natione Britannum.” BA MS S93 sup., 120: "Constantinum cognomento magnum, a Deo delectum qui [...] Italiam tyrannide liberaret ecclesiam adhuc inopem tanti census dote locupletaret: et summo Pontifici, primum quærenti Regnum Dei, diuinitus promissa adijceret ornamenta: in Anglia, Helena brittana cum augusta nunc Diua matre natum, Autorum quae sequuntur testimonia declarant."

60. Matthew 6:33. The Holie Bible, ed. Matthew Parker (London: Richard Iugge, 1568). 
wild)." ${ }^{11}$ Here there is a curious grammatical dislocation between the subject ("Britannia") with its service to the Christian faith ("est tutata") and those unnamed kings who have deserted the true religion (they appear in a dative clause governed by "licet"). In this formulation, it is the island, the land itself, and not its kings, which has served as a "Defender of the Faith." Britain, if not the cradle of Christianity, was then at least one of the first Roman provinces to receive and nurture that religion. ${ }^{62}$

In addition to the Enquiry, Pinelli owned a manuscript version of a work by Shelley that appears to have been copied from an edition, the "Prayer to God by the Prior of England," that includes an imprimatur by a "brother Eliseus" and "brother Angelus Faventinus" of the Inquisition. ${ }^{63}$ As Michael Mulett notes, Shelley was detained by the Inquisition for a period between April 1582 and May 1583. It was perhaps through pressure therefrom that Shelley prepared the "Prayer," expressing his desire in the strongest possible terms for a return of the Catholic Church to England, much as his work on Constantine had anticipated a time when "the Catholic Faith will be restored." 64 The prayer itself asks for divine intervention that Elizabeth might repent and return to the Church of Rome:

\begin{abstract}
And with that same humility of the heart and desire for your glory, he prays that you who are patient and of great pity, grant the unfortunate queen, led astray from the good path, and in every period of her life spurred on by the tempest of her father's schism [...] finally be carried back from the deep into the port of the holy Catholic Church by some experienced admiral. ${ }^{65}$
\end{abstract}

61. BA MS S93 sup., 120r: "quae ipsa (inquit) prima prouinciarum fidem accepit christianum; quam inde ad nostram usque aetatem quibusdem licet Regibus nonnunquam desciscentibus, et aliquando sæventibus continuo tamen est tutata."

62. This subject would be a source of friction some twenty years later between William Camden and Justus Lipsius, with Camden affirming Constantine's British birth and Lipsius firmly (and curtly) refuting it. See William Camden, Gulielmi Camdeni et Illustrium Virorum ad G. Camdenum Epistolae (London: Richard Chiswell, 1691), 64-68.

63. BA MS R109 sup., $248^{\mathrm{r}}$.

64. BA MS S93 sup., 123v: "opusculo;" "Fides catholica restituatur."

65. BA MS R109 sup., 247r: "Et eadem cordis humilitate, Gloriæque tuæ cupiditate, supplicat ut concedas, qui patiens es et multae miserationis misella ut REGINA, seducta atque deuia, et omni aetatis suæ 
The queen's error Shelley ascribes to "either the defect of her education, or the weakness of her age or sex, or else because she is beset by the counsel of others, or puffed up by fawning, or angry with incitements." ${ }^{66}$ Here the "tempest of her father's faith" echoes the "heretical tempest" alluded to above by the author of On the Nature of the English, while "educatio" suggests something of that suspect Protestant education cited by the same. ${ }^{67}$ Intriguingly, Shelley once again takes the opportunity to stress Constantine's British credentials, describing the island as "his homeland and his kingdom," and once again emphasizes that "Britain was the first of all the provinces" to receive the Christian faith "from the pontiff of Rome." ${ }^{8}$ Shelley, acutely aware of England's status in Italy in the wake of the Reformation, is thus eager to stress in both works its historical role in the development and sustaining of Roman Christianity.

Pinelli was also gathering intelligence through an expansive network of scholars and diplomats across Europe. Perhaps tellingly with regard to the kind of information he was able to access, the Venetian authorities intervened after Pinelli's death to confiscate what they deemed to be sensitive material relating to the state. ${ }^{69}$ In a letter to the botanist Carlo Clusio, Pinelli thanks him for his comments regarding Aristotle but also for information "on the commission in England."70 Besides scholarly correspondents, Pinelli would also have been able to gather news and information first hand from the steady stream of visitors to his library. In a letter to his brother sent from Heidelberg in 1598, Sir Henry Wotton (1568-1639) speaks of the special status awarded to the Englishman abroad: "I find myself the only Englishman in this town, and therefore the more desired by the great men here, for the news of those parts; so that every letter

tempore incitata paterni schismatis tempestate [...] perito aliquo a Nauarcho in SANCTAE ECCLESIÆ CATHOLICÆ PORTUM, ex alto denique inuehatur.”

66. BA MS R109 sup., 247: "uel educationis uitio, uel Ætatis, uel sexus imbecillitate [...] aut aliorum uel consilijs circumuenta, uel adulationibus inflata irritationibus stomachata."

67. Elizabeth was certainly an accomplished Latinist, producing translations of Boethius's De Consolatione Philosophiae and Horace's Ars Poetica, and had studied Greek under both Roger Ascham and Henry Savile. See Patrick Collinson, "Elizabeth I (1533-1603)," ODNB; online (Jan 2012 edn.), accessed 10 Oct 2017, oxforddnb.com/view/article/8636.

68. BA MS R109 sup., 247: "Britannia omnium prima Provinciarum."

69. Grendler, 388.

70. Quoted in Rivolta, lviii: “della commissione [...] in Inghilterra.” 
of occurrences in England adds unto me an honour." ${ }^{11}$ It seems probable that Pinelli similarly relied on his English and Scottish guests for the information they could relate on current affairs at home.

Pinelli's collection boasts a letter from Mary Queen of Scots to her councilmen (including "mon petit Erskin") from her imprisonment at Sheffield Castle. Writing from "cette estroite prison" in September 1572, Mary pleads with her counsellors to maintain the Roman faith in her absence:

Je vous prie de mantenir la foi tousjours, en la quelle uous auez este battisez [...] et uous recommande sur touttes choses de uous souuenir que hors de l'Arche de Noe il n'ia aucune saluation: et come uous me tenez pour uostre Princesse souueraine, et Maistresse, ainsi auec moi ie uous prie de recognoistre ung. seul Dieu. Vne foy. Et Vne Eglise Catholique. ${ }^{72}$

Echoing the catechism, Mary thus equates the obedience due to one's monarch with a duty to the church. The letter is juxtaposed with a series of works detailing the final years of the queen's life, including a letter from Sertorio Loschi sent from Paris "on the death of the Queen of Scotland" as well as Francesco Marcaldi's "On the Queen of Scotland until the year 1580."73 Besides his direct correspondence with Pinelli, the same Loschi, "maire du palais des seigneurs Pico," was sending reports to Fulvia da Corregio, countess of Mirandola, regarding the court of Henri III (1551-89), of which Pinelli subsequently commissioned copies. ${ }^{74}$ Marcaldi does not appear to have had direct contact with Pinelli but rather had a commercial approach to the writing and dissemination of such reports, penning "short accounts of Italian and foreign states containing political, economic, and military information." 75

71. Henry Wotton, The Life and Letters of Sir Henry Wotton, ed. Logan Pearsall Smith, 2 vols. (Oxford: Clarendon Press, 1907), 2.235.

72. BA MS C64 inf., $29^{r}$.

73. BA MS C64 inf., unità codicologica 9, "sula morte della regina di Scozia"; 12 "Della Reina di Scotia sino all'anno 1580."

74. BA MS D459 inf., unità codicologica 10. Cf. Marisa Gazzoti, “L'espace symbolique: la cour d'Henri III de Paris à Mirandole," Études de lettres 1-2 (2013): 1-14, 2.

75. Brian Richardson, “A Scribal Publisher of Political Information: Francesco Marcaldi”, Italian Studies 64.2 (2009): 296-313, 297. 
Pinelli was also gathering information on Robert Devereux, Earl of Essex (1565-1601). Preserved in Manuscript R2 Sup. are anonymous letters in French sent to Pinelli from Paris and The Hague (from Loschi perhaps, or a figure with similar diplomatic ties) recounting Essex's rebellion and fate, as well as a French translation of the verdict delivered to Essex by "le grand senechal d'Angleterre":

\begin{abstract}
Puisque voz pairs vous condamnent, ie pronounce, que vous estrez traistre, et comme tel uous serez traisne sur une aije iusque au lieu de l'execution, ou uous serez pendu iusqa demy mort, et la cord coupe uous uoirez uoz membrees diuisez en quatre partz, et uostre teste sera mise sur ung pau en tel lieu quel plairà à la Raigne. ${ }^{76}$
\end{abstract}

This chimes with later English accounts of the judgment delivered to Essex, as, for example, that which is found in The Arraigment, Tryal and Condemnation of Robert Earl of Essex (1679):

Then the Lord High Steward gave Judgement as followeth: You must go to the place from whence you came, and there remain during Her Majesties pleasure, from thence to be drawn on a Hurdle through London Streets, and so to the place of Execution, where you shall be hanged, bowelled, and quartered: your head and Quarters to be disposed of at Her Majesties pleasure. ${ }^{77}$

It is not unreasonable to assume that both versions were relying on contemporary oral and written testimonies circulating after the earl's execution, some of which apparently made their way across the channel at an impressive pace.

Pinelli took an active interest in England and Scotland throughout his life, gathering information on the political and cultural nuances of these nations not only from his network of scholars and diplomats but from the visitors to his library at Padua. From Shelley, he received a patriotic claim to one of Christianity's earliest champions at Rome and a prayer for the restoration of the Catholic faith in England, and from Bruce, a work on English archery that

77. Anonymous, Tryal and Condemnation of Robert Earl of Essex (London: Printed for Tho. Basset et al., 1679), 29. 
boasted lexical curiosities from the English language. The following section explores the poetry by White and Seget now preserved in the Pinelli papers at the Ambrosiana. Their verse, as is explored below, offers a detailed insight into the Pinelli circle and the intellectual and social bonds that connected its members.

\section{Pinelli and poetry: Richard White (1539-1611) and Thomas Seget}

Beyond his enthusiasm for philology, antiquarianism, and the natural sciences, Pinelli also had an eye to poetry. He was a close friend of Torquato Tasso (1544-95), revealed "a considerable interest in the literature of the Italian volgare," and was quick to correct what he saw as a fundamental misreading of Ludovico Ariosto (1474-1533) by Sir Henry Savile. ${ }^{78}$ Pinelli also owned what is now considered to be one of the Ambrosiana's greatest treasures, the Ilias Picta, or "painted Iliad," a manuscript of Homer's epic dated to around the fifth century CE which includes fifty-eight depictions of the text. ${ }^{79}$ The section that follows explores the poetry preserved in the Pinelli papers by White and Seget, the former shedding further light on Pinelli's coterie, the latter bearing witness to his nurturing of the next generation of scholar-poets.

Richard White of Basingstoke, antiquarian and jurist, attended New College, Oxford, in 1555, where he was elected as a perpetual fellow. A devout Roman Catholic, however, he left England permanently in 1560, removing himself to Louvain. Two of the speeches that White delivered at the Law School "to the admiration of many" would subsequently be printed at London as Orationes Duae (1566). ${ }^{80}$ White subsequently travelled to the University of Padua, where he delivered further lectures, subsequently published at Arras in 1596 as the Orationes. While at Padua, he pursued antiquarian interests, and with the help of the printer Lorenzo Pasquato, produced an edition of a curious inscription found in a field outside the city walls of Bologna, a copy of

78. Nick Havely, Dante's British Public: Readers and Texts, from the Fourteenth Century to the Present (Oxford: Oxford University Press, 2014), 88. For Pinelli's censure of Savile and his apparent misreading of Ariosto, see BA MS D. 221 inf., $65^{\mathrm{v}}-66^{\mathrm{r}}$.

79. Grendler, 406.

80. "cum multorum admiratione." Richard White, Orationes Duae (London: Ap. R. Wolfium, 1566), s.p. 
which is now held at the Ambrosiana. ${ }^{81}$ The enigmatic inscription, which White reproduced in full, presents itself as the epitaph of an "Aelia Laelia Crispis":

Aelia Laelia Crispis is neither man, nor woman

Nor hermaphrodite, nor young man, nor

Old woman, nor chaste woman, nor prostitute:

But all things:

She lies neither in the sky, nor on earth, nor in water:

But everywhere. ${ }^{82}$

White's work on the Aelia inscription-which he reads as an enigmatic reference to the metamorphosis of Niobe-would eventually be followed by the Historiarum Libri (1597). ${ }^{83}$ This work consisted of five books on the history of Britain from Brutus to Constantius Chlorus (d. 306), father of Constantine the Great. The works by White preserved at the Ambrosiana, however, are entirely in verse. White was on familiar terms with Pinelli, and wrote a poem in his praise, punning on "Pinelli" and "pinus" ("pine-tree"): "when from the ground you touch the sky with the top of your head / you will no longer be Pinelli by name, but pine," whose "grain should hardly be put before the moronic commons, / but on the tables of kings." ${ }^{4}$ The Pinelli papers contain both rough and fair copies of White's poems, the former in White's autograph, suggesting that they were sent directly to Pinelli by White himself, or perhaps composed onsite at Pinelli's home. With the exception of the pine poem, White's verse forms part of a larger collection of elegies marking the death of the Greek scholar, Michael Sophianus of Chios (which island was held by the Genoese until 1566). Pinelli's biographer, Paolo Gualdo, listed Sophianus first among those scholars who enjoyed the scholar's hospitality at Padua: "Sophianus, from whom, extremely skilled in Greek, Pinelli drew a profound knowledge of that

\section{BA Stampato, S.I.G.V.30/1.}

82. Richard White, Elia Laelia Crispis Epitaphium Antiquum (Padua: Apud Laurentium Pasquatum, 1568), s.p.: "Elia Lelia Crispis neque uir, neque foemina / neque androgyna, neque iuuenis, neque / anus, neque casta, neque meretrix: / Sed omnia: /Neque cœlo, neque terris, neque aquis: sed ubique / Iacet.”

83. See Ovid, Metamorphoses, ed. R. J. Tarrant (Oxford: Clarendon Press, 2004) 163 (6.303-12).

84. BA MS P.242 sup. 38r. "Quando solo, tangis sublimi vertice coelum, / Non iam Pinellus nomine, Pinus eris"; "Grana quidem stupidæ plebe vix ante ferenda / Sed Regum mensis." 
language." ${ }^{85}$ In a letter to Pinelli, Paolo Manuzio (1512-74), son of the celebrated printer Aldo Manuzio (ca. 1452-1515), remembers the "perfect company" he had enjoyed at Pinelli's library, highlighting especially "the intelligence of [Andreas] Dudith," "the eloquence of [Felice] Pacciotto," and "the learning of [Michael] Sophianus." ${ }^{\text {[6 }}$

Following Sophianus's death in 1565, Pinelli gathered rough copies of the elegies and epitaphs written by members of his circle before commissioning fair copies to be made. Besides the five poems by White, the collection also contains contributions from the Portuguese humanist, Aquiles Estaço (1524-81), the aforementioned Paolo Manuzio, the Greek copyist and translator, Nicolaus Petreius (1486-1568), and the scholar Francesco Antonio Vivoli (m. 1613). Intriguingly, the poems appear to be in dialogue with one another, a poetic exchange between peers as they mark the death not only of a great scholar but also of an esteemed friend. In a poem addressed to the Flemish humanist Nicaise Ellebaudt (1535-77), White refers to an elegy already undertaken by the same: "You have wept for this image of ancient Greece, this young man of exquisite nature, with a worthy song [...] if you make this image everlasting, why should I say one word more?" 87 This familiarity with Ellebaudt's elegy suggests a wider exchange and circulation of these poems among Pinelli's acquaintances, forming a shared expression of grief that mirrors their more frequent exchanges of books, ideas, and current affairs. The "Epitaphium," composed by Francisco Davanzati, similarly presents Sophianus as a replica or image of the ancient past:

He whom praiseworthy Chios begat,

Whose name was deservingly taken from "wisdom,"

Famous for his conduct and learning, was an image of those

Men of old whom learned Greece brought forth. ${ }^{88}$

85. Gualdo, 52r: "Sophianus, a quo Graece peritissimo eiusdem linguae hausit intimas notiones."

86. Paolo Manuzio, “A Gio. Vincenzo Pinelli,” Lettere Inedite di Dotti Italiani del Secolo XVI, ed. Antonio Ceruti (Milan: Tipographia \& Libreria Arcivescovile, 1867), 25: "l’ingegno del Duditio"; "l'eloquenza del Pacciotto"; "la dottrina del Sofiano."

87. BA MS N156 Sup., 63": "Extinctum merito carmine fleueris / Antiquae effigiem Graciae, et indole / Perfecta iuuenem. [...] si perpetuam hanc effigiem facis / Cur uerbum ulterius loquar'.

88. BA MS N.156 sup., 60: 'Quem laudata Chios genuit, vir clarus in orbe, / Cui merito a sophia nobile nomen erat / Moribus insignis doctrinaque instar eorum, / Quos tulit antiquos Graecia docta viros." 
White too nods to Sophianus's origins on Chios, and plays on the twin claims made on him by Greece and Italy. In "Onomasticum," White describes the "Latin fathers" bestowing the epithet "wise" ("Sophum") on Sophianus as an adoptive name ("Nomen adoptiuum"), while in "On the Envy of the Fates" ("In Parcarum Inuidiam"), he equates Greece and Italy in their admiration for the scholar. ${ }^{89}$ The longest of the poems by White is the "Complaint to the Muses on the death of Michael Sophianus" ("In Mortem Michaelis Sophiani Expostulatio cum Musis"), in which he arraigns Apollo, Minerva, and the Muses for their failure to protect their own:

Phoebus father of Sophianus the nourisher and protector,

Why were you thus so uncharitable with your beloved foster-son?

And you, Minerva, powerful in arms, terrifying with the

Gorgon's face, menacingly brandishing the spear at the enemy,

Were you not moved by care for your studies?

And you nine sisters (why should I hesitate to say it?),

Could you be thus ungrateful to this your lover? ${ }^{90}$

White plays here on the specific functions that the ancients awarded their deities. With the phrase "exstiteris [...] parcus" (suggesting "you were sparing" or "frugal"), he accuses Apollo of neglecting his "alumno" ("foster-son" or "pupil"), appealing to Apollo's role as a patron of the arts. There is a morbid irony at work, however, and White seems to have an eye to Apollo's role as the God of the sun, in which function he was by no means sparing amid the summer heat ("calores") which took Sophianus's life. ${ }^{91}$ So too he is concerned with Minerva's twin-identity as goddess of war and of the arts, suggesting

\section{BA MS N.156 sup., $62^{\mathrm{r}}-63^{\mathrm{r}}$.}

90. BA MS N156 Sup. 62 $2^{\mathrm{r}-\mathrm{v}}$ : "Phoebe pater Sophiani altor fautorque [...] Cur sic exstiteris tam caro parcus alumno / Tuque Minerva potens armis, et gorgonis ore / Terribilis, quatiensque minaciter hostibus hastam / Nulla te mouit studiorum cura tuorum? / Vosque nouem (quid enim dubitem memorare) sorores / Ingratae ne esse huic vestro potuistis amanti?"

91. The title of the collection's first poems records the circumstances of Sophianus's death: "To Michael Sophianus, who died amid the great heat of 1565, having taken ill at the home of Ferrarianus" ("Ad Michaelem Sophianum qui inter maximos calores anni 1565, apud ferrarianum [...] sese infirmum receperat, estinctus est"), presumably referring to the Greek humanist, Francesco Porto (1511-81) BA MS P242 sup., $44^{\mathrm{r}}$. 
that she has favoured one at the expense of the other, placing arms ("armis") before studies ("studiorum"). Gathered as they are in a collection of verse commemorating the death of a fellow scholar, White's poems speak of the complex connections of the wider group-bound, though of different nations and heritage, by the common pursuit of learning under a shared patronage, a patronage furnished not by Apollo or Athena, who have both failed Sophianus, but by Gian Vincenzo Pinelli.

The poems by Thomas Seget now preserved at the Ambrosiana are also concerned with this kind of relationship with Pinelli, whom he speaks of not only as a patron but also as a father. Seget, born in Seton, graduated from the newly-founded University of Edinburgh in 1588, before studying under the Flemish humanist Justus Lipsius (1547-1606) at the University of Leiden. Seget arrived in Padua in 1597, where he spent almost a full year in Pinelli's company. Lipsius had written a letter of introduction to Pinelli on Seget's behalf, where he speaks of the young man's "keen and excellent intellect" as well as his "eagerness and zeal for learning." 92 This appears to have been sufficient for Pinelli, who readily welcomed Seget into his home. Seget in turn was evidently impressed by Pinelli's learning, praising him in one poem as "versed in antiquity and all wisdom." ${ }^{\text {'3 }}$ Seget's Album Amicorum, now held at the Vatican Library, reveals that he befriended many of his fellow countrymen at the natio Scota while at Padua, and was quickly introduced to Pinelli's circle of scholars, poets, and intelligencers. ${ }^{94}$ Sertorio Loschi, for example, from whom Pinelli had received intelligence on Mary Stewart, was with Seget at Mirandola in October 1599, writing in the Album as "proof of the respect which I bear to the virtues and merits of Signore Tomaso Segheto, Scottish gentleman." ${ }^{95}$

Seget gifted Pinelli with at least two manuscripts from his own collection, both of which are now preserved at the Ambrosiana: an Italian translation of Ovid as well as a copy of Dante's (1265-1321) Commedia.${ }^{96}$ According to

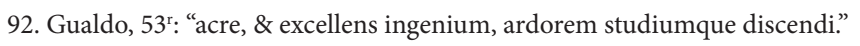

93. D450 inf. u.c. 38: "antiquitatis, omnis et scientiae / Consulte."

94. Biblioteca Vaticana, Cod. Vat. Lat. 9385. Stefano Gattei has produced an edition of Seget's Album Amicorum, accompanied by a richly detailed article on Seget and his works: "The Wandering Scot: Thomas Seget's album amicorum," Nuncius 28 (2013): 345-463.

95. "In testimonio dell'osseruanza ch'io porto alle virtu et ualore del Signore Tomaso Segheto gentilhuomo Scocese." Gattei, 409.

96. BA MS I69 sup.; BA MS C198 inf. For Seget's copy of Dante, see Havely, 79-93. 
Pinelli's biographer, such was the esteem with which Seget was held by Pinelli's family that upon the collector's death, he was appointed as praefectus (an administrator or overseer) of the library by Pinelli's nephew and heir, Cosimo Pinelli. ${ }^{97}$ Following his years in Italy, Seget would publish a collection of poems at Hanau, the Meletemata Ypogeia (1607), which would be reproduced posthumously in the second volume of the Delitiae Poetarum Scotorum (1637), a collection of Neo-Latin poetry by Scottish poets.

In the poetry he wrote for Pinelli, Seget speaks of his host as a second father. The poem preserved in MS S107 Sup., entitled "Thomas Seget the Scot, as he leaves Padua, to Joannes Vincentius Pinellus," was probably written towards the end of $1599 .{ }^{98}$ Here the idea of Pinelli as a father is first introduced by the poem's subtitle-"he was a gentle father"-a phrase that appears four times in the Odyssey in relation to Odysseus. ${ }^{99}$ The appeal to the Odyssey speaks also of the author, drawing an implicit comparison between his impending travels abroad and Odysseus's decade of wandering. Intriguingly, Pinelli, in his short entry in Seget's Album Amicorum, which he penned before Seget's departure, also appeals to Homer:

Keep shooting thus

Joannes Vincentius Pinellus

To Thomas Segetus

Padua, the last day of March, $1599^{100}$

At onelevel, thephrase "keep shooting thus" can be read simply as encouragement for Seget's onward travels. If taken with an eye to its original context in Homer, however, the phrase speaks more obviously of Pinelli's relationship with the young Seget. In book 8 of the Iliad, Agamemnon praises Teucer for his skill with the bow: "Teucer, beloved, son of Telamon, leader of men, keep shooting thus, in the hope that you may become a light to the Greeks and to your father

97. Gualdo, 113-14.

98. BA MS S107 Sup., 85ㄹ: "Ilustri Viro / Ioanni Vincentio Pinello / Patricio Genuati / Thomas Segetus Scotus / Patauio discedens." This poem is also reproduced in Gattei, 52.

99. Homer, Odyssey 1-12, Homeri Opera: Tomus III, ed. Thomas W. Allen (Oxford: Clarendon Press, 1967) 2.47; 2.234; 5.12; idem. Odyssey 13-24, Homeri Opera: Tomus IV, ed. Thomas W. Allen (Oxford:

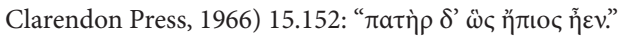

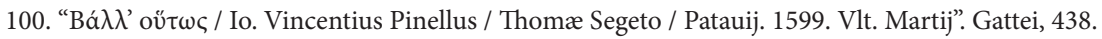


Telamon, who raised you when you where an infant, and though a bastard, took care of you in his home; bring him honour, though he is far away." 101 Seget, if not an illegitimate child, was at least a stranger welcomed by Pinelli into his home as if he were his own. Now Seget, too, is expected to bring his adoptive father honour, albeit from afar.

It is with this sentiment that Seget begins the poem, looking back to his first departure from Scotland and his father's household: "Just as I once left the lares of my father, / Departing from the homeland; so (I swear to God) / I now abandon you, Pinelli, and your lares." ${ }^{102}$ Here Seget appeals to the Roman deities of the household, the lares, and continues to emphasize this foster relationship with Pinelli through the refrain "with you as my father." ${ }^{103}$ Concluding, Seget records something of the network surrounding Pinelli and the rich intellectual opportunities that this afforded:

There was for me in your company the opportunity to enrich the mind with distinguished arts: to make in your company Friends with the greatest of men and to enjoy thoroughly the friends I had made.

$[\ldots]$

Unwillingly therefore I abandon your lares,

Unwillingly therefore I abandon you, Pinelli. ${ }^{104}$

With "copia" ("opportunity" or "plenty"), Seget underlines the intellectual and social opportunities available through Pinelli's acquaintance but also suggests something of the Erasmian "copia," that is, the abundance of lexical and thematic material with which the learned man was expected to equip himself through

101. Homer, The Iliad 1-12, Homeri Opera: Tomus I, ed. David B. Monro and Thomas W. Allen (Oxford:

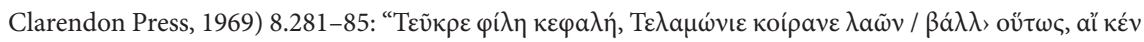

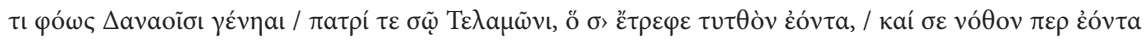

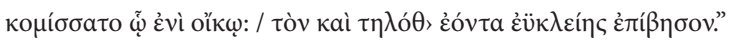

102. BA MS S107 Sup., 85 : "Qualis paternos patria excedens lareis / Olim reliqui; talis (adiuro Deum) / Te nunc PINELLE desero et lareis tuos."

103. BA MS S107 Sup., $85^{r}$ : "te parente."

104. BA MS S107 Sup., 85r: "Mihi tecum honestis artibus copia fuit / Ditare mentem; maximos tecum uiros / Parare amicos et paratis perfrui. [...] Inuitus ergo desero lareis tuos / Inuitus ergo desero PINELLE te." 
his reading. ${ }^{105}$ Having begun with a nod to Homer's wandering Odysseus, Seget concludes with Virgil's far-flung hero, echoing Aeneas's sentiment upon leaving Carthage- "I do not willingly seek out Italy" - with his repeated "unwilling" (“invitus"). 106

The same manuscript contains Seget's "Portrait of the Soul" ("Animi Effigies"), an alternative version of which appears in his Album Amicorum. Here Seget mirrors the "steady mind" with a series of carefully balanced phrases: "no man I hate; I spurn no man"; "a firm tongue, a mild nature"; "deceit I neither suffer nor supply." ${ }^{107}$ In the conclusion to the Ambrosiana version, he switches linguistic registers, slipping from Latin into Greek:

I do not envy the happy man, nor do I take joy In anybody's loss: I live not for myself but for the homeland.

In work and in truth Content with things as they stand. ${ }^{108}$

Here the final line picks up Horace's description of Aristippus in the first book of the Epistles, while the phrase "in work and in truth" he quotes in Greek

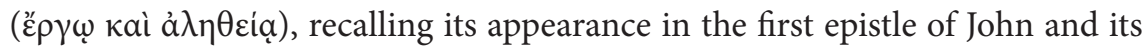
meditation on divine love and communion with God: "my babes, let us not love in worde, neither in tongue: but in deede and in veritie." 109 The patriotic sentiment underpinning "I live not for myself but for the homeland" speaks of another kind of love, namely the Roman emphasis on placing the patria before the individual. To Horace's famous "it is a sweet and proper thing to die for the homeland," we might add Cicero's exclamation in the Philippics: "O blessed

105. Erasmus's De Duplici Copia Rerum ac Verborum, first published at Paris in 1512, was reproduced throughout the sixteenth century, appearing from Venice presses no fewer than ten times.

106. Virgil, Aeneid, 4.264: "Italiam non sponte sequor."

107. S80 sup. $286^{\mathrm{v}}$ : "nullum odi; sperno nullum"; "lingua tenax, mite ingenium"; "fraudem, nec fero, nec facio".

108. S80 sup. 286": "Felici non inuideo, nec gaudeo damno / Cuiusquam: uiuo non mihi sed patriae. /

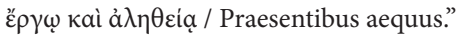

109. Horace, Epistles, Q. Horati Flacci Opera (Oxford: Clarendon Press, 1900) 1.17.24; 1 John 3:18, The Holie Bible, ed. Matthew Parker. 
death, which, owed by nature, has been yielded chiefly for the homeland."110 Immediately before the verse to which Seget alludes above, however, the first epistle of John speaks of the individual's responsibility to lay down one's life for others following the example of Christ: "Hereby perceive we love, because he layde downe his lyfe for us, \& we ought to lay downe our lyves for the brethren."111 Linguistically then, Seget marries Latin and Greek, but ideologically, too, he combines a distinctly Roman sense of virtue and patriotic self-sacrifice with the Christian emphasis on self-sacrifice for the sake of others.

By commenting directly on his relationship with Pinelli, Seget's poems shed further light on Pinelli's role as host and patron, celebrating him as a nurturer of burgeoning talent. Like the poetry by White, Seget's verse touches on both the intellectual and social ties which bound the members of this diverse group together, connected by a common pursuit of learning and their acquaintance with Pinelli and his extraordinary collection.

\section{Conclusion}

He who rests here, buried in calm peace,

will not suffer lengthy songs, however deserving.

Let it be sufficient to have said "Pinelli." The Frenchman, the Italian, the German, the Belgian, the Britain, the Spaniard will say more. ${ }^{112}$

This epitaph for Pinelli, recorded in a letter by Lorenzo Pignoria to Paolo Gualdo, not only suggests the collector's far-reaching reputation-his name is on the lips of each and every European-but also nods to the actual visitors to Pinelli's library who hailed from every corner of Europe and witnessed the man and his vast collection for themselves. This article has examined the Scottish and English scholars who studied with Pinelli and the contributions they made to his library, from calls for the restoration of the Catholic faith in England to the finer points of English archery. The works of Bruce and Shelley

110. Horace, Carmina, Opera 3.2.13: "dulce et decorum est pro patria mori”; Cicero, Philippics, C. Tulli Ciceronis Orationes (Oxford: Clarendon Press, 1916) 14.31: "O fortunata mors, quae naturae debita pro patria est potissimum reddita!"

111. 1 John 3:16, The Holie Bible, ed. Matthew Parker.

112. Pignoria, 73: "Non hic qui placida compostus pace quiescit / Promeritus quamuis, carmina longa feret. / Pinellum dixisse sat esto. Cetera dicent / Celta, Italus, Sueus, Belga, Britanus, Iber.” 
offered Pinelli cultural and antiquarian analyses of England, and thus formed a key part of his wider collection concerning English and Scottish affairs. The poetry of Seget and White speaks directly of their own relationships with Pinelli as a patron and host, offering a detailed insight into the interactions and exchanges of this vibrant and ever-changing community of scholars, poets, and scientists. Pinelli himself revealed an intense interest in the cultural and political frameworks of England and Scotland, inviting his Anglo-Scots visitors to correct discourses and reports that he had gathered on both nations. The Pinelli manuscripts preserved at the Ambrosiana thus offer new perspectives on the wider European traffic of ideas and texts across the latter half of the Cinquecento. The findings explored here suggest that Pinelli's private library also functioned as a complement to and extension of the university of Padua; that his collection and the coterie surrounding it offered a further stage of study and cross-cultural exchange for travelling scholars of all nationalities, not least for the English and Scots. This is a project larger than this article allows, but it seems reasonable to assume that the other major private libraries of Italy were functioning in a similar manner. "Let it be sufficient to have said," however, that Pinelli's name became synonymous among English, Scottish, and European scholars more generally with erudition, collaborative scholarship, and the shared pursuit of learning. 